Language and Language Teaching Journal http://e-journal.usd.ac.id/index.php/LLT Sanata Dharma University, Yogyakarta, Indonesia

\title{
Student's Perceptions on Simulation as Part of Experiential Learning in Approaches, Methods, and Techniques (AMT) Course
}

\author{
Marselina Karina Purnomo \\ Sanata Dharma University \\ marselinakarina@yahoo.com \\ DOI: doi.org/10.24071/11t.2017.200104
}

\begin{abstract}
Simulation is a part of Experiential Learning which represents certain real-life events. In this study, simulation is used as a learning activity in Approaches, Methods, and Techniques (AMT) course which is one of the courses in English Language Education Study Program (ELESP) of Sanata Dharma University. Since simulation represents the real-life events, it encourages students to apply the approaches, methods, and techniques being studied based on the real-life classroom. Several experts state that students are able to involve their personal experiences through simulation which additionally is believed to create a meaningful learning in the class. This study aimed to discover ELESP students' perceptions toward simulation as a part of Experiential Learning in AMT course. From the findings, it could be inferred that students agreed that simulation in class was important for students' learning for it formed a meaningful learning in class.
\end{abstract}

Keywords: students' perceptions, simulation, Experiential Learning, AMT course

\section{Introduction}

Approaches, Methods, and Techniques (AMT) course is the first course that prepares the students to be future English teachers. According to Buku Panduan Akademik Program Studi Pendidikan Bahasa Inggris Universitas Sanata Dharma Yogyakarta (2012), this course is included in Kelompok Mata Kuliah Berkarya $(M K K B)$ or known as Content Courses that introduce ELESP students of Sanata Dharma University who are in semester 4 to learn concepts and principles of certain approaches, methods, and techniques. Through this course, students are prepared to teach using different approaches, methods, and techniques. Moreover, this course invites students to learn how to apply those approaches, methods, and techniques by doing simulation which is based on a real-life classroom.

Furthermore, learning through simulation is a part of Experiential Learning. According to Kohonen, Jatinen, Kaikkonen, and Lehtovaara (2011), Experiential Learning includes various interactive activities through which participants are able to learn from each other's experiences. Those interactive activities are: 1) personal journals and reflections, 2) portfolios, thought questions and reflective essays, 3) role plays, drama activities, games, and simulation, 4) personal stories and case studies, 5) visualizations and imaginative activities, 6) models, analogies and theory construction, 7) empathy-taking activities, story-telling, sharing with others, 8) discussions and reflection in cooperative groups (p.23). It can be seen 
from the list that simulation is indeed a part of Experiential Learning. Keeton and Tate (1978) state that Experiential Learning refers to learning in which a learner is expected to be in touch with the realities being studied (as cited in Kolb, 1984, p.5). In AMT course, students are to learn the application of approaches, methods, and techniques being studied based on a real-life classroom in order to experience it directly.

According to Lewis, Wentworth, Reinke, and Becke (1974), simulation is an imitation of reality in an artificial situation (p. 2). In this study, simulation is used as a learning activity in class to represent real-life classroom situation in order for students to practice how to apply the approaches, methods, and techniques being studied. Thus, students have knowledge of the application of approaches, methods, and techniques which are useful and helpful when they are about to teach later on.

The fact that this is the first course that prepares the students to be future English teachers and that this is the first time students learn how to apply certain approaches, methods and techniques make students' understanding of this course matters the most. For those reasons, this study would like to address one research question, namely what are ELESP students' perceptions toward simulation as a part of Experiential Learning in AMT course? In order to answer the research question, the writer conducted a survey. The instrument used to gather the data was questionnaire which consisted of 28 close-ended statements and 2 open-ended questions. The questionnaire was distributed to every fourth semester students in ELESP who were taking AMT course in the academic year of 2016/2017. The data were analyzed by applying Likert Scale. There were four scales which were used, namely "Strongly Disagree", "Disagree", "Agree" and "Strongly Agree". The writer omitted "Neutral" option in order to know the exact answer from the participants whether they agreed or not.

\section{Perception}

Altman, Valenzi, and Hodgetts (1985) state that perception is the way stimuli are selected by a person so that they can be meaningfully interpreted (p. 85). Referring to the theory, the writer implies that perception is a process where a person selects some stimulus in order to be interpreted into a meaningful information. Nevertheless, Assael (1995) state that what a person perceives or interprets might be different compared to the perception of other people.

A person's awareness and acceptance of the stimuli play an important role in the perception process. Receptiveness to the stimuli is highly selective and may be limited by a person's existing beliefs, attitude, motivation, and personality. Individuals will select the stimuli that satisfy their immediate needs (perceptual vigilance) and may disregard stimuli that may cause psychological anxiety (perceptual defense) (as cited in Borkowski, 2005, p. 54).

Based on Assael's theory, it can be seen that every person perceives things differently based on his goals, needs or motives which lead to either a positive or negative perception. Referring to the previous theory, the writer presents theories on factors affecting perception in order to know the factors affecting ELESP students' perceptions toward simulation as a part of Experiential Learning in 
AMT course. According to Altman, Valenzi, and Hodgetts (1985), there are four factors affecting individual's perception of a certain thing, namely 1) Selection of Stimuli, 2) Organization of Stimuli, 3) The Situation, and 4) The Person's SelfConcept (pp. 86-91).

Selection of stimuli is the first factor affecting individual's perception. Selection of stimuli is where an individual only focuses on a small number of stimuli. Therefore, he perceives things differently for he tends to choose specific cues, filters, etc. The second factor influences perception is an organization of stimuli. This factor focuses on whether the mind is able to arrange the information to become meaningful or not. After an individual selects the information, the mind will try to put them together in a meaningful way based on his experience. Another factor affecting an individual's perception is the situation. This factor gives big impact to an individual's perception of certain thing. The individual's familiarity with, expectations about the situation and also what his or her experience influence what that individual perceives. The fourth factor affecting an individual's perception is self-concept. Self-concept is how a person feels about, perceives, and sees himself as an individual. Every person has different selfconcept on themselves which is why it will affect their perception of the world around them and will cause different perception from one another.

\section{Experiential Learning}

According to Keeton and Tate (1978), Experiential Learning is learning where the learners are expected to be in touch with the realities being studied (as cited in Kolb, 1984, p. 5). Learning through simulation as a part of Experiential Learning allows the students to learn not only from reading theories, books or related references but also to experience directly how to apply the approaches, methods, and techniques based on a real-life classroom. In addition, Kolb (1984:42) state that the model of Experiential Learning consists of two dimensions, they are Prehension Dimension and Transformation Dimension (as cited in Kohonen, Jaatinen, Kaikkonen, and Lehtovaara 2001, pp. 27-28). Prehension Dimension refers to the way the individual grasps experience. Afterward, Transformation Dimension refers to how experience is transformed through reflection and active experimentation. According to Kolb (1984), those two dimensions of Experiential Learning produce "four orientations to learning", namely 1) Concrete Experience, 2) Abstract Conceptualization, 3) Reflective Observation, 4) Active Experimentation (as cited in Kohonen, Jaatinen, Kaikkonen, and Lehtovaara, 2001, pp. 28-29).

Concrete Experience focuses on feeling over thinking by involving personal experiences. Next, Abstract Conceptualization focuses in learning by thinking and manipulating abstract symbols. After that, Reflective Observation focuses on understanding the meaning of ideas through careful observation by focusing on how things happen based on someone's thoughts, feelings, and judgments in seeing things from different perspectives. Thereafter, Active Experimentation focuses on learning by action, with an emphasis on getting things done. Students are expected to learn how to change situations and take risks in order to meet the goals. 


\section{Simulation}

According to L. Jones (1983), simulation is a representation of a series of real-life events (p. 1). In this study, simulation represents a real-life classroom where there is a teacher applies certain approaches, methods, and techniques in a classroom to teach his students. Similarly, Guetzkow (1963) states that simulation has two essential features which must appear before an activity could be considered as a simulation, they are; 1) It must represent a real situation, 2) It must be operational, an ongoing process (as cited in Ellington, Addinall, and Percival, 1981, p. 16). Based on the previous theory, it can be seen what needs to appear in an activity to be addressed as a simulation. However, there might be some questions about teacher's role in the class. Hertel and Millis (2002), state that the instructor, who is the teacher himself, is to help and to be both helper and facilitator instead of judging or testing the students (as cited in Coffman, 2006, p. 2). Moreover, Hertel and Millis (2002) also state that simulation will provide students the opportunity to get involved and participated in real-life experience which will make them become more aware as active participants (as cited in Coffman, 2006, p. 3). Since students have the chance to directly experience how to apply the approaches, methods, and techniques being studied through simulation, it encourages them to be more active as participants.

Additionally, L. Jones (1983) state that simulation is divided into three distinct phases, namely preparation, simulation, and follow-up (p. 3). Those three phases are done by following these 5 steps, namely 1) Preparation in class, 2) Preparation at home, 3) Simulation, 4) Follow-up at home, 5) Follow-up in class. Referring to the theory, the writer intends to figure out whether the simulation in AMT course is based on those steps or not. Furthermore, Brumfield (2005) state that the results of using simulation are not only to help students in the education but also to enlighten students in finding how to apply certain issues or concepts (as cited in Coffman, 2006, p. 3). It improves students' skills in solving some issues and applying certain concepts since simulation allows them to apply the theories and relate them to the real-life context.

\section{Discussion}

Table 1 is presents the students' perceptions toward the concept of perception and factors affecting perception on simulation in AMT course. The table consists of 9 statements covering the concept of perception and factors affecting perception.

Table 1. Students' perceptions toward the concept of perception and factors affecting perception on simulation in AMT course

\begin{tabular}{|c|c|c|c|c|c|}
\hline \multirow{2}{*}{ No. } & \multicolumn{1}{|c|}{ Statements } & 1 & 2 & 3 & 4 \\
\cline { 3 - 6 } & $\mathrm{SD}$ & $\mathrm{D}$ & $\mathrm{A}$ & $\mathrm{SA}$ \\
\hline 1 & $\begin{array}{l}\text { You think simulation makes } \\
\text { the learning in class } \\
\text { meaningful }\end{array}$ & $\begin{array}{c}0 \\
(0 \%)\end{array}$ & $\begin{array}{c}2 \\
(1.36 \%)\end{array}$ & $\begin{array}{c}81 \\
(55.47 \%)\end{array}$ & $\begin{array}{c}63 \\
(43.15 \%)\end{array}$ \\
\hline
\end{tabular}




\begin{tabular}{|c|c|c|c|c|c|}
\hline 2 & $\begin{array}{l}\text { You think simulation done } \\
\text { in class is important for your } \\
\text { learning }\end{array}$ & $\begin{array}{c}0 \\
(0 \%)\end{array}$ & $\begin{array}{c}1 \\
(0.68 \%)\end{array}$ & $\begin{array}{c}89 \\
(60.95 \%)\end{array}$ & $\begin{array}{c}56 \\
(38.35 \%)\end{array}$ \\
\hline 3 & $\begin{array}{l}\text { You think simulation can } \\
\text { make you achieve your goals } \\
\text { in this class }\end{array}$ & $\begin{array}{c}0 \\
(0 \%)\end{array}$ & $\begin{array}{c}6 \\
(4.10 \%)\end{array}$ & $\begin{array}{c}102 \\
(69.86 \%)\end{array}$ & $\begin{array}{c}38 \\
(26.02 \%)\end{array}$ \\
\hline 4 & $\begin{array}{l}\text { You have a hard time in } \\
\text { understanding the simulation }\end{array}$ & $\begin{array}{c}5 \\
(3.42 \%)\end{array}$ & $\begin{array}{c}100 \\
(68.49 \%)\end{array}$ & $\begin{array}{c}33 \\
(22.60 \%)\end{array}$ & $\begin{array}{c}8 \\
(5.47 \%)\end{array}$ \\
\hline 5 & $\begin{array}{l}\text { You can understand the } \\
\text { application of approaches, } \\
\text { methods, and techniques } \\
\text { being studied through } \\
\text { simulation }\end{array}$ & $\begin{array}{c}1 \\
(0.68 \%)\end{array}$ & $\begin{array}{c}10 \\
(6.84 \%)\end{array}$ & $\begin{array}{c}113 \\
(77.39 \%)\end{array}$ & $\begin{array}{c}22 \\
(15.06 \%)\end{array}$ \\
\hline 6 & $\begin{array}{l}\text { You think facilities used in } \\
\text { this course support you to do } \\
\text { the simulation }\end{array}$ & $\begin{array}{c}3 \\
(2.05 \%)\end{array}$ & $\begin{array}{c}19 \\
(13.01 \%)\end{array}$ & $\begin{array}{c}102 \\
(69.86 \%)\end{array}$ & $\begin{array}{c}22 \\
(15.06 \%)\end{array}$ \\
\hline 7 & $\begin{array}{l}\text { You think the class's } \\
\text { situation supports you to } \\
\text { conduct simulation }\end{array}$ & $\begin{array}{c}1 \\
(0.68 \%)\end{array}$ & $\begin{array}{c}27 \\
(18.49 \%)\end{array}$ & $\begin{array}{c}98 \\
(67.12 \%)\end{array}$ & $\begin{array}{c}20 \\
(13.69 \%)\end{array}$ \\
\hline 8 & $\begin{array}{l}\text { You believe that through } \\
\text { simulation you can pass this } \\
\text { course with good grade and } \\
\text { deep understanding }\end{array}$ & $\begin{array}{c}1 \\
(0.68 \%)\end{array}$ & $\begin{array}{c}22 \\
(15.06 \%)\end{array}$ & $\begin{array}{c}103 \\
(70.54 \%)\end{array}$ & $\begin{array}{c}20 \\
(13.69 \%)\end{array}$ \\
\hline 9 & $\begin{array}{l}\text { You believe that simulation } \\
\text { implemented in this course } \\
\text { can improve your ability in } \\
\text { teaching }\end{array}$ & $\begin{array}{c}0 \\
(0 \%)\end{array}$ & $\begin{array}{c}3 \\
(2.05 \%)\end{array}$ & $\begin{array}{c}93 \\
(63.69 \%)\end{array}$ & $\begin{array}{c}50 \\
(34.24 \%)\end{array}$ \\
\hline
\end{tabular}

Note: SD: Strongly Disagree, D: Disagree, A: Agree, SA: Strongly Agree

From the results of table 1, it can be seen that there are few negative perceptions toward the concepts and factors affecting perception toward simulation in AMT course. Students agree that facilities in class and situation of the class do not support them to conduct the simulation and sometimes they have a hard time in understanding the simulation. Referring to the open-ended questions, students state that situation of the class is too noisy for students are busy with themselves to pay attention to the simulation. Likewise, facilities in class also need to be improved for sometimes it is hard for them to find a marker. Students also state that sometimes they have difficulties in understanding the simulation since the simulation does not cover the theory from the book and students who are to do the simulation are not well-prepared. In that way, the data from the open-ended questions present the reasons behind the negative perceptions found in the close-ended statements.

However, from the result of table 1, the writer discovers that students tend to have positive perceptions toward simulation in AMT course. It can be seen from the results of the close-ended questions in table 1 that most of the students agree with the statement that simulation is important for it makes the learning in class meaningful. Students agree that through simulation they are able to achieve their goals which are to understand the application of approaches, methods, and techniques being studied. Furthermore, students agree that simulation improves their ability in teaching and also facilitates them in obtaining deep understanding 
toward the course. Referring to the open-ended questions, the students state by doing simulation they know how to implement some techniques, to use different methods, and to implement the materials in the class. Most of all, students state that simulation facilitates them in achieving their goals which are to understand more about the approaches, methods, and techniques being studied and to check whether their teaching is good or not. Thus, through open-ended questions, the readers can see the reasons behind the positive perceptions found in the closeended statements.

Next, in order to further study the students' perceptions toward simulation, the writer presents table 2 which is about students' perceptions toward learning through simulation as a part of Experiential Learning in AMT course. In the table presented below, there are five statements covering the definition of Experiential Learning and its' four orientations.

Table 2. Students' perceptions toward learning through simulation as a part of Experiential Learning in AMT course

\begin{tabular}{|c|c|c|c|c|c|}
\hline \multirow[b]{2}{*}{ No. } & \multirow[b]{2}{*}{ Statements } & 1 & 2 & 3 & 4 \\
\hline & & SD & $\mathrm{D}$ & A & $\mathrm{SA}$ \\
\hline 10 & $\begin{array}{l}\text { You are encouraged to learn } \\
\text { approaches, methods, and } \\
\text { techniques by practicing through } \\
\text { simulation instead of only reading } \\
\text { theories }\end{array}$ & $\begin{array}{c}6 \\
(4.10 \%)\end{array}$ & $\begin{array}{c}18 \\
(12.32 \%)\end{array}$ & $\begin{array}{c}72 \\
(49.31 \%)\end{array}$ & $\begin{array}{c}50 \\
(34.24 \%)\end{array}$ \\
\hline 11 & $\begin{array}{l}\text { You think simulation can help you } \\
\text { to involve your experiences in the } \\
\text { learning process }\end{array}$ & $\begin{array}{c}0 \\
(0 \%)\end{array}$ & $\begin{array}{c}0 \\
(0 \%)\end{array}$ & $\begin{array}{c}102 \\
(69.86 \%)\end{array}$ & $\begin{array}{c}44 \\
(30.12 \%)\end{array}$ \\
\hline 12 & $\begin{array}{l}\text { You can learn more about the } \\
\text { approaches, methods, and } \\
\text { techniques by observing other } \\
\text { group's simulation }\end{array}$ & $\begin{array}{c}1 \\
(0.68 \%)\end{array}$ & $\begin{array}{c}15 \\
(10.27 \%)\end{array}$ & $\begin{array}{c}94 \\
(64.38 \%)\end{array}$ & $\begin{array}{c}36 \\
(24.65 \%)\end{array}$ \\
\hline 13 & $\begin{array}{l}\text { You think simulation helps you to } \\
\text { understand more about the } \\
\text { theories of approaches, methods, } \\
\text { and techniques being studies }\end{array}$ & $\begin{array}{c}0 \\
(0 \%)\end{array}$ & $\begin{array}{c}9 \\
(6.16 \%)\end{array}$ & $\begin{array}{c}94 \\
64.38 \%)\end{array}$ & $\begin{array}{c}43 \\
(29.45 \%)\end{array}$ \\
\hline 14 & $\begin{array}{l}\text { You think simulation provides } \\
\text { opportunities to practice the } \\
\text { application of approaches, } \\
\text { methods, and techniques you have } \\
\text { learned in real-life classroom }\end{array}$ & $\begin{array}{c}0 \\
(0 \%)\end{array}$ & $\begin{array}{c}3 \\
(2.05 \%)\end{array}$ & $\begin{array}{c}105 \\
(71.91 \%)\end{array}$ & $\begin{array}{c}38 \\
(26.02 \%)\end{array}$ \\
\hline
\end{tabular}

Note: SD: Strongly Disagree, D: Disagree, A: Agree, SA: Strongly Agree

From the results of table 2, the writer discovers that students have positive perceptions toward learning through simulation as a part of Experiential Learning in AMT course. Based on the data, the writer can infer that through simulation, students are able to involve their experiences in the learning process, learn more about the application approaches, methods, and techniques by observing other group's simulation, understand the theories of approaches, methods, and techniques more, and experience the application of approaches, methods, and techniques instead of only reading the theories. Referring to the open-ended 
questions, the students state that simulation encourages them to learn by involving their experiences in using those approaches, methods, and techniques to teach in a real-life classroom. In addition, they also obtain a better understanding of the theories for they need to understand it first before implementing the theories in the simulation. Therefore, the data from the open-ended questions presents the reasons behind the positive perceptions found in the close-ended statements.

To be more precise about students' perceptions toward simulation, the writer presents table 3 which is about students' perceptions toward the implementation of simulation in AMT course. In the table presented on the next page, there are 14 statements covering the definitions of simulation, the role of the teacher, in simulation, simulation's phases, and simulation in education.

Table 3. Students' perceptions toward the implementation of simulation in AMT

\begin{tabular}{|c|c|c|c|c|c|}
\hline \multicolumn{6}{|c|}{ course } \\
\hline \multirow[t]{2}{*}{ No. } & \multirow[t]{2}{*}{ Statements } & 1 & 2 & 3 & 4 \\
\hline & & SD & $\mathrm{D}$ & $\mathrm{A}$ & SA \\
\hline 15 & $\begin{array}{l}\text { You think simulation implemented } \\
\text { in this course is based on a real-life } \\
\text { classroom }\end{array}$ & $\begin{array}{c}0 \\
(0 \%)\end{array}$ & $\begin{array}{c}30 \\
(20.54 \%)\end{array}$ & $\begin{array}{c}97 \\
(66.43)\end{array}$ & $\begin{array}{c}19 \\
(13.01 \%)\end{array}$ \\
\hline 16 & $\begin{array}{l}\text { You think simulation can be } \\
\text { conducted to represent the real } \\
\text { application of approaches, } \\
\text { methods, and techniques being } \\
\text { studied }\end{array}$ & $\begin{array}{c}0 \\
(0 \%)\end{array}$ & $\begin{array}{c}12 \\
(8.21 \%)\end{array}$ & $\begin{array}{c}120 \\
(82.19 \%)\end{array}$ & $\begin{array}{c}14 \\
(9.58 \%)\end{array}$ \\
\hline 17 & $\begin{array}{l}\text { You think simulation makes you } \\
\text { more active in class }\end{array}$ & $\begin{array}{c}2 \\
(1.36 \%)\end{array}$ & $\begin{array}{c}19 \\
(13.01 \%)\end{array}$ & $\begin{array}{c}87 \\
(59.58 \%)\end{array}$ & $\begin{array}{c}38 \\
(26.02 \%)\end{array}$ \\
\hline 18 & $\begin{array}{l}\text { You think that by doing simulation } \\
\text { you get motivated to learn more }\end{array}$ & $\begin{array}{c}1 \\
(0.68 \%)\end{array}$ & $\begin{array}{c}25 \\
(17.12 \%)\end{array}$ & $\begin{array}{c}83 \\
(56.84 \%)\end{array}$ & $\begin{array}{c}37 \\
(25.34 \%)\end{array}$ \\
\hline 19 & $\begin{array}{l}\text { You think that simulation helps } \\
\text { you to practice how to be a teacher. }\end{array}$ & $\begin{array}{c}1 \\
(0.68 \%)\end{array}$ & $\begin{array}{c}1 \\
(0.68 \%)\end{array}$ & $\begin{array}{c}75 \\
(51.37 \%)\end{array}$ & $\begin{array}{c}69 \\
(47.26 \%)\end{array}$ \\
\hline 20 & $\begin{array}{l}\text { You think simulation can enlighten } \\
\text { you about your function as a } \\
\text { teacher later }\end{array}$ & $\begin{array}{c}2 \\
(1.36 \%)\end{array}$ & $\begin{array}{c}8 \\
(5.47 \%)\end{array}$ & $\begin{array}{c}89 \\
(60.95 \%)\end{array}$ & $\begin{array}{c}47 \\
(32.19 \%)\end{array}$ \\
\hline 21 & $\begin{array}{l}\text { You think the lecturer of this } \\
\text { course helps you solve your } \\
\text { difficulties without judging and } \\
\text { testing you. }\end{array}$ & $\begin{array}{c}4 \\
(2.73 \%)\end{array}$ & $\begin{array}{c}21 \\
(14.38 \%)\end{array}$ & $\begin{array}{c}79 \\
(54.11 \%)\end{array}$ & $\begin{array}{c}42 \\
(28.76 \%)\end{array}$ \\
\hline 22 & $\begin{array}{l}\text { You think that simulation always } \\
\text { begins with a preparation in the } \\
\text { class. }\end{array}$ & $\begin{array}{c}1 \\
(0.68 \%)\end{array}$ & $\begin{array}{c}23 \\
(15.75 \%)\end{array}$ & $\begin{array}{c}82 \\
(56.16 \%)\end{array}$ & $\begin{array}{c}40 \\
(27.39 \%)\end{array}$ \\
\hline 23 & $\begin{array}{l}\text { You think through simulation you } \\
\text { are encouraged to be well-prepared } \\
\text { by reading related books or } \\
\text { references at home. }\end{array}$ & $\begin{array}{c}4 \\
(2.73 \%)\end{array}$ & $\begin{array}{c}16 \\
(10.95 \%)\end{array}$ & $\begin{array}{c}87 \\
(59.58 \%)\end{array}$ & $\begin{array}{c}39 \\
(26.71 \%)\end{array}$ \\
\hline 24 & $\begin{array}{l}\text { You think the amount of time to do } \\
\text { the simulation is enough }\end{array}$ & $\begin{array}{c}3 \\
(2.05 \%)\end{array}$ & $\begin{array}{c}39 \\
(26.71 \%)\end{array}$ & $\begin{array}{c}90 \\
(61.64 \%)\end{array}$ & $\begin{array}{c}14 \\
(9.58 \%)\end{array}$ \\
\hline
\end{tabular}




\begin{tabular}{|c|l|c|c|c|c|}
\hline 25 & $\begin{array}{l}\text { You think the written work at } \\
\text { home helps you to extend your } \\
\text { understanding of the approaches, } \\
\text { methods, and techniques being } \\
\text { simulated. }\end{array}$ & $\begin{array}{c}7 \\
(4.79 \%)\end{array}$ & $\begin{array}{c}40 \\
(27.39 \%)\end{array}$ & $\begin{array}{c}86 \\
(58.90 \%)\end{array}$ & $\begin{array}{c}13 \\
(8.90 \%)\end{array}$ \\
\hline 26 & $\begin{array}{l}\text { You think the follow-up discussion } \\
\text { after the simulation extends your } \\
\text { understanding of the approaches, } \\
\text { methods, and techniques being } \\
\text { simulated. }\end{array}$ & $\begin{array}{c}0 \\
(0 \%)\end{array}$ & $\begin{array}{c}3 \\
(2.05 \%)\end{array}$ & $\begin{array}{c}108 \\
(73.97 \%)\end{array}$ & $\begin{array}{c}35 \\
(23.97 \%)\end{array}$ \\
\hline 27 & $\begin{array}{l}\text { You have deep understanding of } \\
\text { this course through simulation }\end{array}$ & $\begin{array}{l}0 \\
(0 \%)\end{array}$ & $\begin{array}{c}25 \\
(17.12 \%)\end{array}$ & $\begin{array}{c}107 \\
(73.28 \%)\end{array}$ & $\begin{array}{c}14 \\
(9.58 \%)\end{array}$ \\
\hline 28 & $\begin{array}{l}\text { You think simulation done in class } \\
\text { enables you to apply the } \\
\text { approaches, methods, and } \\
\text { techniques properly }\end{array}$ & $\begin{array}{c}0 \\
(0 \%)\end{array}$ & $\begin{array}{c}19 \\
(13.01 \%)\end{array}$ & $\begin{array}{c}106 \\
(72.60 \%)\end{array}$ & $\begin{array}{c}21 \\
(14.38 \%)\end{array}$ \\
\hline
\end{tabular}

Note: SD: Strongly Disagree, D: Disagree, A: Agree, SA: Strongly Agree

From the results of table 3, the writer discovers that there are several negative perceptions from the students toward the implementation of simulation in AMT course. Students agree that the situation of the class should be improved and also that the amount of time to do the simulation should be added. Referring to the open-ended questions, students state that situation of the class in the simulation should be improved for students do not act like real students. Furthermore, students state that they need more time to do the simulation. In that way, we can see that the data from the open-ended questions elaborate students' negative perceptions toward the simulation which later could be considered as suggestions to improve the implementation of simulation in AMT course.

Despite the fact that there are several negative perceptions, it can be inferred from the results of table 3 that most of the students' perceptions toward simulation are positive. The writer discovers that the phases of the simulation done in class are the same with the supporting theory. First, simulation implemented in class always begins with a preparation in class. Second, students get to prepare the simulation by reading related references or books at home. However, most of the students think that the time to do the simulation is not enough. Then, there is follow-up at home by doing written work on the question about the discussion of the materials being simulated and follow-up at class after simulation where students accept feedback from the lecturer. From the data, the writer can also imply that students agree that simulation enlightens them about the function of a teacher, motivates them to learn more, helps them to practice to be a teacher, and facilitates them in obtaining better and deeper understanding. The writer also discovers that the lecturer acts as a facilitator who helps students by giving feedback instead of judging them. Referring to the open-ended questions, students state that simulation motivates them to find the best method to teach, to conduct productive class, to master the materials before delivering them to the students and to have loud voice volume and good eye contact as a teacher. Additionally, students state that they become more active as participants in class through simulation for they are motivated to learn how to be good teachers. Furthermore, 
students state that they always obtain feedback from lecturers which they use to improve themselves. Therefore, students can achieve deeper and better understanding of AMT course and can apply the approaches, methods, and techniques properly.

\section{Conclusions}

Based on the research findings and discussion, it can be seen that more than $80 \%$ of the students have positive perceptions toward simulation as a part of Experiential Learning in AMT course. There are several conclusions that can be inferred from the research findings and discussion. First, students are motivated to be more active and to learn more by learning how to apply approaches, methods, and techniques instead of only reading theories. Second, the students have the chance to involve their personal experiences in learning how to be teachers and how to function as teachers based on real-life classroom. Third, the students have deep understandings of this course through simulation. Fourth, students are able to apply approaches, methods, and techniques properly. Therefore, it can be concluded that students agree that simulation is important for it makes the learning in class meaningful. Based on the research findings, the writer would like to suggest the lecturers of AMT course to set some rules to encourage students to be more serious and to pay attention to conduct and learn the simulation, to give more examples on how to simulate certain approaches, methods, and techniques in order for students to be able to do the simulation properly, to always check whether the simulation represents a real-life classroom or not in order for students to get accustomed to being a teacher, to consider adding extra time to do the simulation. Next, future writers are suggested to focus more on the different implementation of simulation between one class and another in order to know the reasons and objectives behind it.

\section{References}

Altman, S., Valenzi, E., \& Hodgetts, R. M. (1985). Organizational behavior: Theory and practice. Orlando, Florida: Academic Press, Inc.

Assael, H. (1955). Attitudes and Perceptions. In N. Borkowski (Eds.), Organizational behavior in health care. Retrieved November 24, 2015 from http://healthadmin.jbpub.com/borkowski/chapter3.pdf

Brumfield, R. (2005). How simulations enhance learning. In T. Coffman (Eds.), Using simulations to enhance teaching and learning: encouraging the creative process (p.3). Retrieved November 1, 2015 from https://www.vste.org/documents/vj_2006_02.pdf

Darkenwald, G. G., \& Merriam, S. B. (1982). Experiential Learning Methods. In B. P. Beaudin \& D. Quick (Eds.), Experiential learning: theoretical underpinnings (p. 18). Retrieved November 13, 2015 from http://users.ugent.be/ mvalcke/LI_1213/experiencial_learning.pdf

DePoy, E., \& Gitlin, L. N. (2015). Introduction to research: understanding and applying multiple strategies ( $5^{\text {th }}$ ed.). Retrieved November 15, 2015 from http://bookzz.org/book/2569518/5985b0 
Evans, N. (1992). Exploring Experiential Learning. In J. A. Moon (Eds.), A handbook of reflective and experiential learning: theory and practice. Retrieved September 27, 2015 from http://perpustakaandeajulia.weebly.com/uploads/1/8/2/6/18261275/a_handbo ok_of_reflective_and_experiential_learning__theory_and_practice.pdf

Guetzkow, A. (1963). In Ellington, H. Addinall, E., \& Percival, F. (1981). Games and simulations in science education. London: Kogan Page.

Hertel, P. J., \& Millis, J. B. (2002). How simulations enhance learning. In T. Coffman (Eds.), Using simulations to enhance teaching and learning: encouraging the creative process (p. 3). Retrieved November 1, 2015 from https://www.vste.org/documents/vj_2006_02.pdf

Inbar, M., \& Stoll, C. S. (1972). Simulation and gaming in social science. New York: The Free Press.

Jones, K. (1985). Designing your own simulations. New York: Methuen \& Co.

Jones, L. (1983). Eight simulations for upper-intermediate and more advanced students: controller's book. Cambridge: Cambridge University Press

Keeton, M., \& Tate, P. (1978). The foundations of contemporary approaches to Experiential Learning. In D. Kolb (Eds.), Experiential learning: experiential as the source of learning and development. New Jersey: Prentice Hall, Inc.

Kohonen, V., Jaatinen, R., Kaikkonen, P., \& Lehtovaara, J. (2001). Experiential learning in foreign language education. Harlow: Pearson Education.

Kolb, D. (1984:42). Towards experiential foreign language education. In V. Kohonen, R. Jaatinen, P. Kaikkonen, J. Lehtovaara (Eds.), Experiential Learning in foreign language education. Harlow: Pearson Education

Kothari, C. R. (2004). Research methodology: Methods and techniques (second revised ed.). Retrieved February 15, 2015 from http://www.suza.ac.tz/saris/download/132376585119680689-ResearchMethodologyMethods-and-Techniques-by-CR-Kothari.pdf\%202.pdf

Lewis, Jr., Darrell, Wentworth, D., Reinke, R., \& Becker, W. E. (1974,). Educational games and simulations in economics. New York: Joint Council on Economic Education.

Lindsay, P., \& Norman, A. D. (1977). Attitudes and Perception. In N. Borkowski (Eds.), Organizational behavior in health care. Retrieved November 24, 2015 from http://healthadmin.jbpub.com/borkowski/chapter3.pdf

Losby, J., \& Wetmore, A. (2012). CDC coffee break: using likert scales in evaluation survey work (p. 4). Retrieved November 19, 2015 from http://www.cdc.gov/dhdsp/pubs/docs/cb_february_14_2012.pdf

Pinsonneault, A., \& Kramer, L. K. (1993). What is survey research? In P. A. Glasow (Eds.), Fundamentals of survey research methodology (p.1-1). Retrieved November 14, 2015 from www.uky.edu/ kdbrad2/EPE619/Handouts/SurveyResearchReading.pdf 